\title{
Negotiating the Popular and the State
}

Caracas, 2009: I could see that Miriam was about to work herself up. We had gone to the Military Museum in 23 de Enero for a large community meeting. The theme for the meeting was how the communal councils were to adapt to the new law for the communal councils that had just been passed. ${ }^{1}$ On the way out Miriam was stopped by a woman from a nearby communal council. The woman was already quite agitated, shouting that people in the communities were fed up, that they had handed in projects, but that nothing happened. "What does one have to do," she shouted. "Go to the offices and get naked? The bureaucracy is killing the revolution, the revolution is here, with Chávez," she said, touching (or rather beating) her chest. "But this is destroying the process." Miriam asked what they had done, where they had handed in projects, "because here I am, jalando bolas (dragging their balls) for the community to hand in projects." "We have handed them to the municipality," the woman answered. "But not to Fundacomunal?" Miriam inquired. "No," the woman said. "Why not, if you had handed the project to Fundacomunal, you would have gotten your pavement by now." "But that is the problem," the woman shouted, "they tell you to go to Fundacomunal, to the municipality, to the ministry, to the presidency, but what, this is the problem!"

The discussion continued, back and forth for a while; they spoke about a letter that had been handed in, about a project that had been handed in, about a temporary halt of the funding of housing projects in order to incite people to develop other projects as well. Miriam told her that rather than formandome peos a mi (scold me) at the community meeting,

(C) The Author(s) 2017

185

I.Å. Strønen, Grassroots Politics and Oil Culture in Venezuela, DOI 10.1007/978-3-319-59507-8_7 
she should rather go to Fundacomunal, to formar peos there, so that the complaints were made visible to the institutions. "The problem is a lack of response from the institutions," she said. "Look, like I am telling you, the other day we got a hold of la Corporación de Servicios, and they got their ass moving; don't you see that they are working? Why? Because in that meeting we had with them, all of us were all over them." She was referring to the service branch of the municipality in charge of garbage collection and cleaning. In a meeting the other day the community and Miriam herself had been telling them off, demanding better services.

Afterward Miriam and I walked home together; both of us living only ten minutes away. She was really upset. "I get angry really fast, I am the one that got shouted at," she says, maintaining that the real problem was that the institutions high up didn't dar respuestas (give answers). "And besides, now I have to organize yet another meeting because many of my communal councils didn't show up." Miriam was responsible for all the communal councils in the whole of 23 de Enero. I asked her if she had asked to get a co-worker to help her out. "Yes, but they just say that 'you can do it.' I have walked all day in the street, since 8 o'clock (12 hours), and now I get home and my husband is there with his cara de culo (literally: ass face) ... I am quitting, I will look for another job.”

In Chap. 6, we sketched up the conflictive and contradictory faultlines between the ideals of the Bolivarian process and the messy reality of how it actually unfolded within the domains of the state. Drawing on emic conceptualizations of the root causes of all the problems- "the endogenous right," "the boliburgesia," "los cuartarepublicanos," "the institutions," "the bureaucracy"-a quite gloomy picture emerged of a state that was caught up in its own power dynamics rather than executing state policy. Moreover, a picture was also painted of a political process and ideology that was incapable of superseding the exclusionary and hierarchical nature of the political domain that it so strongly criticized. However, while popular sector activists experienced many challenges, they also experienced many small and big victories. Concurrently, while the state in many respects was characterized by structural inertia and deep contradictions between ideal and practice, the Bolivarian process did also carve out a host of new practices, rationalities and cultural politics into the state body.

In order to get a better grasp on these complexities, this chapter is dedicated to delving deeper into state-society interaction within the Bolivarian 
space. I will explore the multiple struggles and strategies deployed by ideologically oriented grassroots activist and public officials in order to convert the ideals of the Bolivarian process into everyday political practice. Invoking the ethos of popular power, people were confronting and contesting the exclusionary and hierarchical practices of the Venezuelan state. At the same time, the rationalities of state governance was put up against popular knowledges in a process that was eclipsed by the Bolivarian government's political ideology of transferring state power to el pueblo soberano (the sovereign people). Concretely, this ideology was manifested in policies and directives that in its legal framework and in its ideological framing had the potential to empower popular power at the expense of state power. However, as Ferguson (1994) also shows from his influential account from Lesotho, policies tend to take on a life of their own when faced with complex material, political and social realities. In a similar fashion, the participatory politics promoted by the Chávez government generated new and contested dynamics both within the state institutions and in the communities when the policies were sought carried out in practice.

\section{Betwixt and Between: The Promotores Integrales}

We will start our exploration by continuing to focus on Miriam, who is introduced in the vignette above. She is an example of the many highly conscientious and ideologically oriented public sector workers that truly believed in the ideals of the Bolivarian process, and who became central for defending government policy inside the state institutions and in converting it into reality in popular sector communities. Her job was to be a promotor integral in Fundacomunal, the "front line" public employees that were working directly with the communal councils. Her task was to help them with whatever challenges they were facing: organizing and constituting themselves, developing and executing projects, or resolving internal problems and quarrels in the communities. In spite of her frustrations, Miriam didn't quit her job as she fretted over above, and over the years I often followed her throughout her workday, both in the communities, in public meetings and visiting public institutions. The demands put on her and her co-workers were not easy. The promotores were poorly paid, and it was an exhausting job, both mentally and physically. They had to subir cerro (climb shantytown hills) by foot, be in the baking sun, take buses and metros, use toilets and ask for water in private barrio homes. At the same time they had to fill out paperwork to prove that they were attending to the communities, and participate in political and public meetings and training sessions. 
I suggest that the promotores occupied an ambiguous betwixt-andbetween position in relation to the communities and the state. They came from poor communities, and many of them worked in their own communities, or in those nearby. At the same time, they were at the bottom of the institutional hierarchy and their experiences and field observations were often ignored by their superiors. This positioned them in a difficult situation in the communities. People viewed them as "agents of the state" who could help in getting projects approved, while many promotores actually had little influence over which projects were approved. These decisions were made elsewhere, higher up in the system, through a process that was often intransparent to the promotores themselves.

This ambiguous social and professional positioning implied that many of the promotores had a dual identity with regards to whom they felt that they were most closely identifying with or representing: the communities or the state. Like Miriam was saying above: "In the same way you are formandome peos a mi (scolding me) here, you have to go to Fundacomunal to formar peos there." What she meant was that castigating her at the meeting in the community did little good. Rather, the communities, or the woman in this case, would have to approach Fundacomunal's offices directly in order to make their complaint visible to the institutions. Through this statement, Miriam signalized that she felt she neither embodied, sympathized with, nor had control over the "institutions." Rather, state power was located elsewhere, and the communities had to make their anger visible where that power held seat, namely in the institutions; in "the realm of officialdom."

\section{Miriam's RoAd to Revolution}

Miriam was constantly frustrated over the way the institutions were working. For her, working with community organizations was deeply political and personal. Her motivation came from her love for Chávez and her belief in the revolution, and despite not being well versed in political theory, she had a keen intuitive understanding of the politics of class, of Latin America's colonial and imperial history, and of the transcendental role of the state in concretizing social transformation. But above all, she was an idealistic pragmatist, and she confronted her numerous daily challenges with a sarcastic attitude and a big heart.

Miriam was a middle-aged woman, married to a taxi driver and mother of two teenage daughters. In many ways, she was a representative of the female backbone supporting the Bolivarian revolution; she was one of 
those numerous popular sector women who had experienced a political awakening with Chávez's arrival on the political scene (Fernandes 2007; Rakowski and Espina 2011; Motta 2013; Strønen 2013).

Her journey toward becoming a "revolutionary" had been long. As a young woman, she had started hanging out in 23 de Enero when she met the man who later became her husband, a native of 23 de Enero. There, she witnessed el Caracazo and later joined the political mobilization around Aristóbulo Istúriz, who served as mayor of Municipio Libertador for La Causa $R$ in the 1993-1996 period.

And when the things with Chávez started, that is when I really got strengthened, and I got really, really strengthened .... and when the coup, when they took Chávez, that was when ... how do you say it, it's like, when something is taken away from you, when someone dies, that is when you really value that person ... when I felt that they took Chávez away from me, it was like they took our soul away.

That is when I really got strengthened ... it was the esqualidos that really strengthened me and a lot of others as well when they took him away, that is when I got strengthened as a Chavista, because I am more a Chavista than a revolutionary, you see? I love that man. Imagine. So, no se metan (they better not screw him over) because we don't know how we will react $\ldots$ he has people behind him and loads of women behind him, we are loads of women, more women than men. Imagine this bunch of women against these esqualidos if they screw Chávez over...

Miriam was educated through the Frente Fransisco De Miranda, and had just graduated when I first met her in 2009. She had taken her courses and done her internships in Venezuela, as the program, previously in Cuba, was moved to Venezuela. She wished for and got a job in Fundacomunal as a promotor through a female friend who temporarily served as a director. In spite of her frustrations, she loved her job:

I like my job, I love my job, I like what I do ... I have worked Iselin, I've had a lot of jobs, I have worked in Pizza Hut, in Burger King, in private companies, in factories ... I have sold hotdogs, the only thing that I haven't done is work as a whore in a bar and that I will never do ... I have worked as a buhonera (selling stuff in the streets), I have cleaned toilets....

I studied as well, I took various courses, courses about everything, I studied accounting, administration and started to work in a tourism enterprise and that's when I started to work in administration, without university studies, but with my courses and the practical knowledge that I possessed, I worked there for 12 years, I changed over to the sales department, I did very well there. 
Afterwards I couldn't take it anymore with the political problems, with Chávez, I supported him and the boss was esqualido ... so I left and I don't want to work anymore in the private business, and well, God heard me and helped me with a job that I like...

\section{Knowing El Pueblo}

Miriam often felt that she had to fight to get support on the job and for the communal councils she was serving. The institutional structures of Fundacomunal were departmentalized and hierarchically organized, with limited flow of information between the director and the ground people such as herself. She felt that her knowledge of "what was happening on the ground" was not sufficiently respected or sufficiently taken into account when decisions were to be made. Moreover, the director of Miriam's office cultivated a circle of "loyal" people, while shutting out those who did not jalar bolas (suck up). As she found herself in the latter category, she felt that it was often difficult to have the ear of her superiors.

In her view, Fundacomunal was hampered by both political and institutional problems. On the one hand, Chávez's political directives of transferring power to el pueblo were not followed up on as they should. This was particularly worrisome because Fundacomunal was the frontline political institution mandated to empower the communal councils. However, instead of truly being a transformative entity making itself an effective tool for popular activism, it continued reproducing the vices of the "institutions" and "the bureaucracy" through institutional opaqueness. Added to this, the institutional legacy of Fundacomunal in terms of being hierarchically organized and still having staff originating from the Fourth Republic made it into an inefficient tool for co-operating and engaging effectively with poder popular (popular power). To Miriam, these were matters of grave concern, because the institution's shortcomings and inability to dar respuestas (give answers), made people hablando paja (talking bullshit) about both Chávez and the revolution.

\section{A Cadre for the Revolution}

Moreover, Miriam was utterly frustrated with many of her co-workers. Some of those working with her didn't care about their work: for them, it was just a way to cobrar (get paid), she alleged. They came to work in the morning, signed in, and then did nothing. As a consequence, communities that were assigned a promotor that didn't care about his or her work recieved poor or 
no support, which led to people losing faith in the government and in the revolution. She, on the other hand, viewed her job as a political task, which was what motivated her to continue her work in spite of her frustrations.

I am always telling the communities that this is thanks to el Presidente, these are the achievements of el Presidente, the missions, this is what he wishes for you, he wants you to study, he wants you to organize yourselves, and I explain all this about what the president wants, why the laws were made, why the Ley Habilitante was passed, all these things....

But I don't get too elaborate, because people don't like that, I talk to them in the colloquial way that we talk, you see? One has to talk to el pueblo in their own language-yes, sometimes it is necessary to discuss, but then you discuss with the people who are up for it ... but with el pueblo in an assembly, you cannot ... because people get bored, and instead of listening to you they start to yawn, the same thing has happened to me and I start to think of birds and stuff ... so you have to say things very pointedly...

For Miriam, the job as a promotor meant being a social worker, a politician, a pedagogue and, not least, an expert in conflict resolution:

You have to climb the cerros (shantytown hills) with them, trudge, assess people's necessities, be a humanist, see if they are carrying out the housing projects, listen to the señora, see if the communal councils are doing what they are supposed to do, find a way to try again, to act, to help, so that they don't get into trouble there.

As is clear from her accounts, Miriam sees herself as embodying the Bolivarian revolution, not the state. For her, the state is a corrupting force, evidenced by the lack of responsiveness that she saw around her. In spite of being part of el pueblo herself, she saw herself as a guide, instructing people and socializing them into becoming new citizens capable of taking on their new role in a new society. This was also Roberto's view, another promotor with Fundacomunal, also trained by the Frente Fransisco de Miranda. In an interview, I asked what he liked most about his job. This is what he answered:

The contact with el pueblo, because that is part of this conjuncture, it is the state ... through my work, taking it to el pueblo ... it is like one of Che's theories, that the cadre takes the grand decision of the state, makes them his and communicates them to el pueblo, trying to also make el pueblo assume it as theirs. So that is why this is a really beautiful job, you have direct contact with el pueblo, you see their realities, you make decisions, you are like an intermediary between el pueblo and the state. 
Of course, we have deficiencies in what comes back, in the dialectic you could say, but that is what we are working towards ... as part of the state one feels that one is contributing with solutions for el pueblo and that is the beautiful part, the direct contact with el pueblo, to make them the state, to transform them into state (volverlo estado, transformarlo en estado).

The promotores were the ones most frequently in contact with the communities. Basically, they were the state's "eyes and ears," with ample room for making their own personal judgments and choosing how to exercise their role. The promotores weren't distant "state officials." Rather, they knew well la gente (people) and how local dynamics were playing out in the communities. On a separate occasion, I chatted with Roberto about the problems in many of the communal councils, and the conflicts between different fractions and different interests. Most often there were conflicts between those who protected their own interests, and those who tried to stay true to the communitarian ideals that the communal councils represented. He said dryly that one always knows what la gente (people) are like. He could go to a community and immediately see "who is who" and what is going on: who is the cheat, who wants to work for the community, who is the idealist, who is the opportunist, who has a leadership role, who aspires to become a leader, who supports their work and who does not. In order to be a good promotor you had to know how to deal with la gente. As Miriam once stated in her matter-of-fact way: "Cuando veo los peos los mato rapidito" [when I see the problems surging I quell them immediately].

\section{O Inventamos O Erramos}

At least in the beginning, the signals from above were not to be too rigid about enforcing rules and regulations in communal council proceedings. The idea was that, if things became too formalized and bureaucratic, people in the communities would get de-motivated and lose interest. The impetus was rather to let both public institutions and communities learn along the way, and to let the thousands flowers blossom. At the same time, the organizational framework supporting the communal councils was still in the making, and Fundacomunal was struggling to adapt to the new legislation, caught up in internal issues and understaffed. Many of the promotores that were hired to work with the communal councils were uncertain about how to do their job. Indeed, there were no public servants that were entirely prepared for working with communal councils. 
After all, theirs was a completely new legal and organizational figure that had yet to be incorporated into the rest of the state bureaucracy.

Thus, Chávez's order was for institutions to learn to work with el poder popular, and he had el Frente Fransisco de Miranda assume responsibility for co-ordinating and managing the core institutions that would work with the communal councils. The idea "to learn as they went along" was epitomized by the phrase 0 inventamos o erramos (either we invent or we err). That was a phrase coined by Simón Rodriguez, Simón Bolívar's friend and teacher, talking about forming Gran Colombia. Chávez frequently held this phrase up as a guiding proverb, arguing that the bourgeois state had to be dismantled, and that a new state, el estado popular (the popular state) had to be built bit by bit. It could not be a pre-designed model, but rather an organic product of emerging social dynamics and the progressive accumulation of knowledge. Thus, just as the numerous missions had been launched "overnight" through the collective effort of state institutions and popular organization, communal councils would start functioning in the same manner.

\section{A Hybrid Space}

The next case study illustrates the modes of interaction between promotores and communities, and provides ethnographic details about how the processes of learning by trial and error were playing out "on the ground." As will emerge from this story, the social dynamics in each communitylas realidades (the realities) - as the promotores often said, were shaping community dynamics. Internal conflicts and alliances, and local notions of social space, structured the legal and organizational framework of the communal councils. The boundaries between the popular sectors and the state were difficult to discern, simply because the state effect (Mitchell 1999) had not yet been grinded into shape. Mobilization was taking place in a hybrid space between institutional and legal frameworks that were not yet concretized and much less enforced and systematized. "Popular" ways of doing things were flourishing in the absence of public officials that knew how to enforce state policy or had internalized their role and agency as representatives of the state. This produced a hybrid space, I will argue, whereby the communities tentatively tried to "become" communal councils, yet steeped in complex local socialities shaping those processes. At the same time, public officials were also trying to learn "how to become the state" while at the same time upholding the principle of promoting el poder popular. 


\section{O Inventamos O Erramos in Practice}

April 2009: it was 8 am, early on a Sunday. I met Miriam down by the Agua Salud metro station in 23 de Enero. Together with Miche, a colleague of hers who normally worked in another parish, we went to do an inspection of the work of some of the communal councils in the area. The inspection had been scheduled because Chávez had recently instructed Fundacomunal to evaluate how the communal councils were progressing before he authorized the injection of new funds for a new round of projects. I greeted Miriam and Miche, and we jumped on a camioneta that took us to a community in the eastern part of 23 de Enero. When we got there, Miriam walked us over to the house of the vocera (spokesperson) in the communal bank. She was a middle-aged, short woman, and originally Colombian. Her daughter, as well as some of the other voceros from the finance committee, was also present.

Miche and Miriam started talking in a friendly but inquiring manner about how things had been going with the housing and rehabilitation project. It soon turned out that there had been some irregularities. The communal council in place when we visited that day was not the original communal council. The original council had split into two branches: one above the road and one below the road. According to the woman, they had received technical assistance from the municipality in doing so. Miche and Miriam made it clear that this was against the law. It was only Fundacomunal that could supervise and approve the constitution of communal councils. Who the representative from the municipality was and what his or her real involvement might have been was never clarified.

Additionally, the communal council could not present bills for its purchase of construction materials as checks were made out to individuals. This was a clear breach of the duty to rendir cuentas (present accounts) to the community and to Fundacomunal. No social comptrollership committee had been monitoring how the projects were proceeding and how the money was being spent. The communal council had hired an external co-operative to do the work. The co-operative had been recommended to them by the Ministry of Health that had previously hired them to set up a health module in the sector. However, the money dried up before the projects were finished and a lot of the work was left incomplete. Some of the money had also been used on a medical emergency in the community and on the purchase of some take-away lunches. The women were in obvious distress over this and Miche and Miriam were not too hard on them, saying that this was not an irregularity in itself as long as it was approved 
by a community assembly. The problem was that they had not convoked such an assembly.

The original project was to restore 27 houses and substitute 5 , for a total amount of 870,000 Bs.F. Allegedly, the vocera had received part of the funds $(15,000 \mathrm{Bs} . \mathrm{F})$ to remodel her own house. She was in fact showing us her house, which was obviously in the midst of a renovation. The discussion was going back and forth, and the lady was explaining as best she could. Both Miriam and Miche were laid-back and non-confrontational, though I could tell that they were subtly trying to understand what had actually happened. Miche was more concerned with recommending that they confront the co-operative that had abandoned the work than with confronting the woman from the communal bank. He strongly recommended that they organize a construction co-operative themselves, within the community, consistent with the government's focus on desarrollo endogeno (endogenous development), so the money could be returned to the community in the form of local labor.

After more discussions, the women accompanied us to a neighboring house. While walking, Miriam pointed out to me that the woman seemed nervous. She and Miche commented that something obviously had gone wrong there; they didn't even represent a legally constituted communal council. However, they couldn't only blame the communal councils; Fundacomunal was also to blame as it hadn't done sufficient technical follow-up, Miche said. Moreover, it seemed as if Fundacomunal hadn't given them any technical assistance in developing the project in the first place, and that was one of the reasons the budget didn't cover the work once the co-operative started the construction process. The co-operative should have detected this, Miche said, but he wasn't sure of what their role in this mess had actually been.

The next house we entered was a typical Venezuelan family barrio house on three levels, where extended family and in-laws lived together. The family had originally received money to renovate the second floor. However, in the course of the process, they had decided to use parts of the money on the third floor of the house, where the niece lived. We climbed up the narrow stairs to the third floor. The head of the family was enthusiastically trying to explain what he had done and how he had done most of the work himself in order to make the money last longer. Miche had a very diplomatic attitude while he made clear that, while he congratulated him with the work done, it was illegal to use the allocated money for something other than what it was originally intended for. Decisions on how to 
employ the money are made by a community assembly and recorded on a legal document. However, he underscored that he wasn't there as an enemy. "As I am institution, and thus part of the state, I come to find out what was done with the money."

When we finally left the house, we moved on to the casa de alimentación (communal kitchen). They had received money to upgrade the kitchen through another project. A poster of Chávez hung on the wall, over a large stack of bags of rice.

We were served coffee, and stood there for a while talking with the women in the kitchen and in the communal bank. Miche underlined to

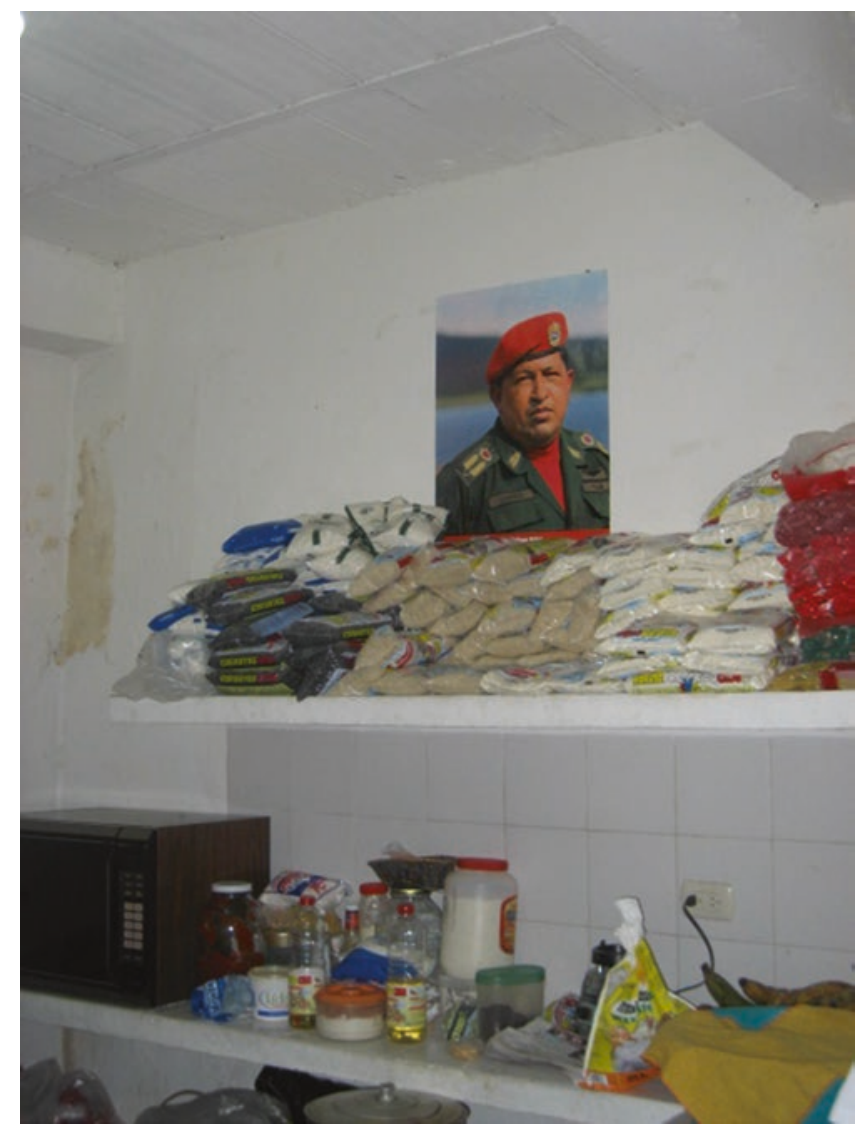

Photo 7.1 A Casa de Alimentación (soup kitchen) in 23 de Enero. Photo by the author 
the community members that they were not there to create problems for the community, rather to find solutions. The problem, as he saw it, was that there seemed to be a lack of unity in the community, which was why the communal council had split in two in the first place. Miriam stated that they should have started with collective projects in communal areas, such as sidewalks or parks, before taking on housing projects. "It is very difficult to carry through such a large housing project si no hay communidad (if there isn't [a sense of] community)," she said, "and we don't want people to be like in the east (in the middle and upper class areas) where they eat inside the house and don't know their neighbors."

As we continued walking, Miche, Miriam and I fell a bit behind the others. Miche and Miriam agreed that the problem was apathy-if the community doesn't get involved, there is space for personal interests to take over the project. Miche said that he understood that the woman in the communal bank had been under a lot of pressure by others in the community. "When they see that the money is being channeled down (se bajan los recursos) they want more and more." "And the institutions must be selfcritical on this point," he said, "because if the community is left without proper guidance, it becomes difficult for the spokespersons to manage the issues right and hence withstand the pressure."

We continued our walk for a few more hours. Some of the families we visited were reasonably content, while others were outraged with both the communal council and the co-operative. One man exclaimed: "It is all a big trap." He had been forced to pay a large part of his new roof himself, as the work was abandoned before it was finished.

After the tour, Miche, Miriam and I went over to a nearby health station where a larger community meeting was scheduled to take place later that evening. We sat down, tired after a long day in the baking sun. Miriam and Miche spoke among themselves about what they thought had happened. Obviously, someone had cut a deal with someone, and someone had been left out, and the woman was obviously nervous because she knew that they couldn't present the bills and they knew that things hadn't taken place according to procedures. "But I don't know if they gave in for pressure from the community and the co-operative, or if they opted for anarchy," Miche said. The problem was also that there had never been any social comptrollership in the community. All communal councils are obliged to have a committee for social controllership that checks that the money is spent according to the budget. However, Miche didn't seem particularly upset over the day's events. Rather, he was quite pragmatic about it: "It isn't corruption as such, but rather misuse of funds. They are 
gente humilde (humble people)." And, he underlined, they hadn't been properly followed up on by the institutions, which made it very difficult for them to carry out the project according to established procedures. The experience with the communal councils was still very new, and the communities were unaccustomed to managing such amounts of money, he asserted.

\section{Exercising Popular Power}

The following day I met up with Miche and Miriam again in the morning in order to do an inspection in another communal council-this time in Antimano, one of the poorest barrios in Caracas. Because of this, the community was considered a high-priority area, ${ }^{2}$ and had a lot of projects approved. We jumped on the metro from Agua Salud to El Capitolio before we changed to another metro line and reached the metro station Antimano. The barrio of Antimano is an impressive sight: the facades were painted a few years back as part of one of the first government urban housing projects. The whole hillside looks like a painter's palette, each facade painted in different colors.

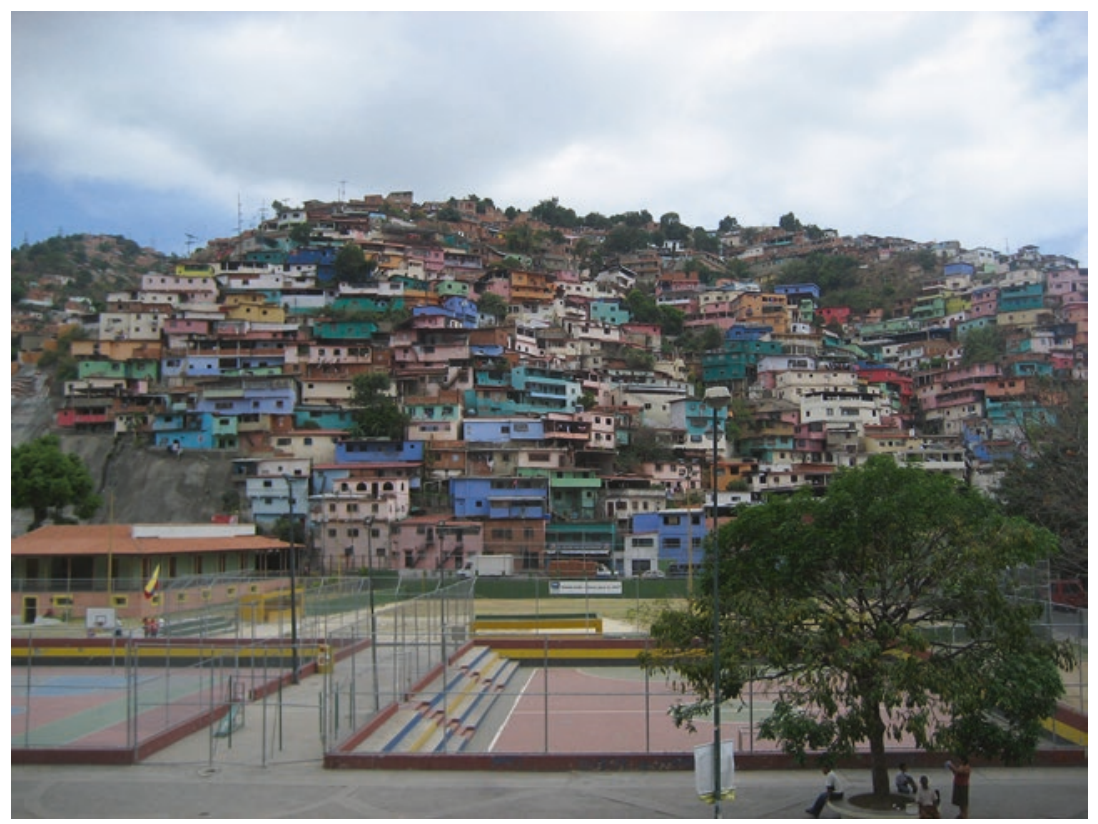

Photo 7.2 The barrio of Antímano. Photo by the author 
It was still early in the morning and none of us had eaten breakfast yet, so we sat down in an arepa joint outside the metro station waiting for the community leader that would pick us up. The most common morning snacks for Venezuelans are empanadas, deep fried flour pastries in the shape of a half-moon. The most common fillings for empanadas are cheese, or seasoned shredded beef, chicken, fish or minced meat. The treat is typically accompanied by soft drinks of freshly squeezed juice. It is really tasty, but it also explains the high obesity rate and the high sales rate of seltzer in Venezuela.

We had just finished eating when the community leader Pedro arrived. He was a friendly man in his 50s sporting a cowboy hat, with an air of natural authority. He explained that their communal council was a semirural communal council, located on the fringes of the barrio in a fertile area. That meant that their council did not include 200 to 400 families as councils of high-density urban areas did. Theirs was limited to 40 to 80 houses.

In addition to the housing projects that we were there to inspect, they had managed to make a sports center, to install a PDVAL (government sponsored mini-market) and to restore the stairways into the community, he told us. Their long-term goal was to establish a commune together with four other communal councils in the area. However, the time was not right, he said, because the other communal councils hadn't started functioning properly yet.

We approached the fringes of Antimano, where their barrio was, on a hill surrounded by trees, vegetation and some cleared land. His family's house was located in the upper part of the community, an impressive and large building with an amazing view over the whole valley. We were taken to the office from which the communal council was operating, a little space at the back of his house. They had made several large posters of all the different project and community events, complete with photos and drawings. Here were posters of the staircase project, the Dia de los Niños (Children's Day) party and the housing project event. The paperwork was organized in neatly marked paper files, stacked on a shelf, and a computer was sitting on a desk.

Miche and Miriam asked about who had carried out the housing project. "We chose the solution that suited the community best," Pedro said. Through assembly meetings the community had simply decided to divide the money equally between all the households. They had 34 carpenters and 31 construction workers living in their community, he informed. So instead of hiring an outside company or co-operative, they had done the 
work. Miriam asked if they had gotten help from an engineer, but Pedro responded that, no, they knew how to resolve their problems and had solved everything themselves. Now all the projects were finished, except for one house for which they had run out of money. In the next couple of days they would arrange a memoria y cuenta (report and account) in a community assembly where each household would present a report on how money was spent.

When Miriam had finished looking over the papers, we started the inspection, going from house to house. Some houses were in very poor condition and had been completely rebuilt, while others were in fairly good condition and had seen more "luxurious" upgrades, such as ceramic tile floors. People were visibly satisfied and explained to us in detail the work they had done. Afterward, we were escorted by Pedro to the small community super-market, PDVAL, which also functioned as a communal kitchen. There, we were served dinner by some of the women in the community. Afterward we sat out on the patio while Miriam filled out the paperwork with Pedro before he drove us back to the metro station.

A couple of days later, we returned for the memoria y cuenta event, which was on the patio outside Pedro's house. A large circle of chairs was set up under the shade of some trees. Pedro told Miche and Miriam that they had gone from house to house and informed people about the meeting, collecting their signatures, which confirmed they had received the message. One by one, they explained to the group what they had done with their house. One woman started to cry out of gratefulness and happiness. She was so relieved over finally having a vivienda digna (dignified home). One man directed his gratitude to "God and to el Comandante." All in all, 36 homes had benefited from the project.

When everyone had explained what they had done with the funds, Miche made a small speech. He said that he was very happy with the work of this communal council, even if they had distributed the money equally among all households instead of distributing according to a community census over who were in most need. Nevertheless, he viewed their work as very positive, and said it was a true expression of poder popular. He maintained that in many communal councils, people were trying to implement projects by the book, and instead ended up fighting. He encouraged the community to collect some money in order to repair one of the stairs he thought was in dire need of repair, as the elderly woman who lived there had problems climbing up and down the staircase to get to her house. 
He thought they were ready to launch some socio-economic projects. "Recently the communal councils in Caracas have just been concerned with bricks, cement and sand, and we all know that it is necessary, but we also know that there are a lot of other needs here as well, like culture and socio-productive activity." Pedro said that they had a seminar scheduled for the next day about agricultural production and that they had already received credits from Fondemi ${ }^{3}$ for different socio-productive activities like the production of sweets and pastry, a sowing project and painting and carpentry businesses. The meeting was dismissed shortly thereafter and Pedro drove us back to the metro station. Both Miche and Miriam were in a very good mood on the ride home. They expressed great satisfaction over how the community had been able to ejecer poder popular (exercise popular power), organizing themselves in a way that benefited the common good.

\section{TeXtures of Relations}

From the ethnographic accounts above, we can discern the complex dynamics surrounding the communal councils, as well as the texture of relations (Gupta 1995:215, cited in Sharma and Gupta 2001) between the realm of the state, represented by the promotores, and the realm of the popular sectors.

As we have previously discussed, social and spatial configurations in a neighborhood shape people's knowledge of each other, the degree of social trust, the degree of social cohesion and their assessments of common needs and priorities. To outsiders, the barrio seems like a chaotic labyrinth with few apparent borders and boundaries. From the inside, people have a keen awareness of what is on the inside, on the edges and on the outside of "their community"-even if it is not inscribed on a map. Consequently, you also have a sense of who are "your" people, and who are "the others"- those in the barrio over there, those in the bloques down there, those who use the stairways over there, those who have just set up a shack settlement over there. All these factors contribute to the particular dynamic surrounding the unfolding of a communal council.

As we will discuss below, the importance of anchoring communal councils in people's own socio-spatial identities were not at all lost at lawmakers, and it was also of great importance to popular sector activists. However, at times, communal councils were formed that didn't necessarily conform to "natural boundaries." As in the case with the first communal council that I 
visited with Miriam and Miche, this at times lead to splits and the forming of new communal councils. Both of them immediately captured that there was a low degree of social identification and cohesion in the community, and that this was an underlying partial cause for the irregularities and lack of transparency in the communal councils' proceedings. Consequently, Miriam's advice to the community was that they should have started with collective projects bringing them together in a joint cause, rather than housing projects benefiting individual households.

Another key issue was the existence of leadership figures in the community. In the first communal council, leadership roles in the communal council were assumed by a group of people that apparently had no trajectory or experience as local leadership figures in the past. Consequently, Miche and Miriam speculated if they had been subjected to pressure from other community members as well as by external actors, and directed their critique toward the institutions for not providing enough support and guidance.

In the other communal council, Pedro came off as the undisputed local leadership figure in the barrio. Both his aura, attitude and property (his house was much nicer than the rest, and he also had quite a bit of land attached to it) indicated that he was a resourceful person. Moreover, the community itself, as a semi-rural community with quite defined edges, contributed to enhanced mutual social identification. Miriam and Miche captured and understood these dynamics, and even if they at one occasion called Pedro the local "patron," they acknowledged that he had used his power to (as far as they could gather from our two visits) bring the community together in a transparent and relatively friction-free process.

In short, Miriam and Miche viewed the unfolding of the communal councils both through the lens of "the local realities," at the same time as they assessed how the communal councils were faring according to the directives of the state. However, given that the order from above was to let the thousand flowers blossom, they adapted a pragmatic position, estimating success in terms of social achievements for the community rather than strict adherence to the legal framework. For them, as well as for many state legislators, the communal councils were not only about using state money to execute local development projects. They were also means to a superior end: to promote participation and social cohesion in the communities in order to strengthen poder popular. These experiences were building blocks for the communal state that eventually was to replace the bourgeois state (see Ciccariello-Maher 2016). As a member of the national assembly, 
who had been central in developing the law for the communal councils commented:

We define the communal councils as a broad popular organization as defined by article 2 in the law [for the communal councils] .... They should be a space for the articulation between citizens, between popular movements, between social movements and all the expression for popular power that exist within a geographical area, which we have called a geographical communitarian space (espacio geográfico communitario) where the communal council is seated ... this is a strategical intention (linea estratégica) linked to the development and profoundization of direct democracy, of participatory democracy, of popular democracy.

From these formulations, we can discern how the ideological and discursive framing of the communal councils from "the heights of power" put emphasis on the exercise of popular agency. Consequently, as agents of the state as well as popular subjects, Miriam and Miche viewed themselves not as Weberian disinterested public officials, but as cadres whose job it was to guide and empower people to assume a new form of citizenship in alignment with the idea of a radical participatory democracy in the making. It was a delicate balance, for they understood all too well that the communal councils lend themselves to conflicts and not-so-noble actions and maneuverings. Thus, their role was to try to steer things in the right direction through maneuvering in local landscapes as well as providing critical feedback to the state institutions.

\section{Development From Below}

In many respects, the knowledge production surrounding the communal councils was in alignment with insights provided by critical development scholars and analysts (e.g., Pigg 1996; Cooke and Kothari 2001; McNeish 2001). Development projects can very uneasily be mandated from above in a pre-designed manner. Rather, projects need to be firmly rooted in the social realities, local populations and specific needs in the locality which they are intended to benefit.

Some scholars have been highly critical of the communal councils, arguing that they promoted clientelism, co-optation and patronage (Machado 2009; Alvarez and García-Guadilla 2011; López 2011). While this is certainly one aspect of it, it is also important to recognize not only the 
social and human gains that they generated, but also the effects that these experiences had in terms of advancing local organizational skills and capacities. In those communities where communal councils did work out well, it often generated both community cohesion and significant welfare improvements. Innumerable people had their housing standard upgraded, or were relocated to new houses in the cases where they were living in gravely substandard- or dangerous housing. (Many barrio houses are built in landslide-prone areas, and it is not uncommon that people lose their lives when their houses collapse.) To popular sector households, which might spend years and decades slowly improving their housing standards, the ability to add an extra room to their home, to install a bathroom with an actual door, to have a cement floor instead of a dirt floor, to put up a roof that did not leak when it rained, constituted an enormous enhancement of their quality of life, and not least for their sense of dignity. Many communal councils also prioritized upgrading local infrastructure such as roads, passages, stairways, parks and sewage systems, as well as local sports facilities and other collective welfare improvements.

Moreover, from a scholarly perspective, it is paramount to analyze their evolvement within the real-life context within which they were unfolding (see also Ellner 2009; Irazábal and Foley 2010). Promoting "development" and popular empowerment is never a straightforward process, not least in contexts as socially and materially complex as shantytown communities historically shaped by entrenched socio-economic inequalities and socio-cultural marginalization (e.g., see Willson 2007). The development of each communal council-for better or worse-was conditioned by local modes of sociality, local spatial configurations, localized interpretations of needs, existing social resources as well as the support they received from state institutions. Moreover, the features characterizing different communities were not "static" characteristics. Over the years, I observed that different communities went through different phases and stages as the communities gradually accumulated collective knowledge about the legal, bureaucratic and administrative aspects of managing the communal councils. Some managed to resolve conflicts, while others entered into new ones. The communal councils constituted a steep learning curve, whereby "local development scapes," to paraphrase Appadurai (1990) were gradually fostered as social relations and local needs were increasingly reconceptualized through the framework of the communal councils.

The promotores, in time, also became more skilled in their work; though, here too, there were differences among them. There was a quite 
high turnover rate among the promotores, and not all of them were apt at working with popular sector communities. I also occasionally heard rumors that some of them abused their position in various manners, for example, through charging a "cut" from approved grants, or by undue meddling in local struggles for power. At the same time, other promotores, like Miriam, became very skilled in mediating local conflicts and trying to steer the communities toward doing things "by the book" and for the common good. Many promotores also became deft at nudging the right state offices and officials in order to help "their" communal councils.

\section{Schools for Popular Power}

In the course of the first few years, it became evident, both to the lawmakers and the institutions in charge of supporting and financing them, that there was a need to strengthen the communal councils' capacity to concretize and develop projects. Moreover, people asked for more support and guidance from the institutions as project development generated a lot of confusion and problems. For that purpose, workshops were organized in the communities, part of what were called escuelas de poder popular (schools for popular power), oriented toward providing both ideological, political and technical education to the communal councils through "educational cycles" organized across the country.

On one occasion, I attended a workshop in 23 de Enero, called taller de formulación de proyectos (workshop for formulating projects). The meeting was led by Juan Roberto, a promotor from Fundacomunal. There were 14 people present from different communal councils; all but one were women. The goal was to help people concretize their problems, and translate them into a project that could be submitted to state institutions for financing. The workshop was divided in two parts; the first part was a theoretical explanation of methodology, and the second one was a session on the application of the methodology to a project's development. Juan Roberto explained that people often confused "themes" with problems, which hindered their ability to find solutions. For example, people would say that "garbage" or "safety" were their problem. However, Juan Roberto stated, these were not problems, these were themes that had to be concretized into specific projects. A "problem" could be, for instance, the lack of a sports field in the local community, which could then be developed into a project step-by-step. He shared some points (Table 7.1), which could be used to facilitate this process. The points consisted of: 
Table 7.1 Points from workshop discussions about how to analyse and elaborate a community project. The parish of 23 de Enero, Caracas, February 2010

- Definition of the problem (the location of the problem, who is affected by it and for how long people have been affected, i.e., the lack of a sports field in the community la Camboya affecting children and adolescents, and a total of 200 families for the past 10 years)

- The name of the project (reflecting exactly on what the project is about, i.e., sewing elegant dresses)

- Amount of money required to carry out the project

- How long it will take to carry out the project

- Where the project will be carried out, and by which communal council

- Description of the problem

- Cause(s) of the problem

- Why it is worthwhile to implement the project, i.e., what will be gained from it

- What is the motivation for carrying out the project

- What will the concrete result be once the project is finished

- Who will participate in the project, who is responsible

- Development of a step-by-step plan for how the project will be carried out, including follow-up and control

Throughout the workshop, Juan Roberto used concrete examples of common communal council activities: building a sports field, setting up a local project for sewing women's clothes, or building a new pipe system. People were eagerly participating by sharing their points of view, contributing the experiences from their own communities. Juan Roberto managed to engage people without seeming patronizing, and he demonstrated intimate knowledge of the nitty-gritty details of community development planning, such as the diameter of the tubes needed to upgrade sewage systems, and the challenges of sending toddlers to kindergartens on the congested camionetas traversing the barrios in the morning. In fact, Juan Roberto lived in Casalta 3, the same area I was living in at the time, and was therefore very familiar with the barrio reality.

\section{Metis and Popular Power}

In the example above, Juan Roberto has attempted to concretize formal procedures for project development through drawing on people's skills and knowledges about their own social and material realities. The Bolivarian discourse put much stress on the inherent differences between the knowledge of the state and popular knowledge. Popular knowledge 
was understood as the knowledge that people had accumulated through their real-life experiences in their particular (challenging) environment, or what was sometimes referred to as los saberes del pueblo (the peoples' knowledges). In fact, the way popular knowledge was conceptualized came very close to Scott's (1999) concept of metis: "a wide array of practical skills and acquired intelligence in responding to a constantly changing natural and human environment" (Sunstein 1998). Scott maintained that communities that were marginal to market and states had to acquire a high degree of metis out of necessity, "as they have to rely disproportionally on the knowledge and materials at hand" (Scott 1999:335).

People often referred to popular knowledge as an open referent, as something that constituted a wide array of skills, knowledges and life experiences. It referred to the constant creativity and improvisations needed in order to construct your barrio house with scarce resources. It referred to people's accumulated and collective knowledge about soil conditions and local topography, about the improvised constructions of sewage systems and electricity grids, about the intricacies of buildings and constructions that were built and intertwined onto and into each other, within any engineer telling them when the construction had reached its maximum bearing capacity. It referred to the creativity of making ends meet, and about their capacity to organically organize in the face of collective needs and crisis. It was a form of knowledge rooted in a deep knowledge about their social environment, in the genealogy of the barrio and sector they were living in, in the myths, memories, and stories underpinning local social identities.

In short, popular knowledge was drawn from the dense experiences of living life on the margins of society and the official economy, to live in a culture of urgency (Pedrazzini and Sanchez 1992) that often produced hardships, but also enormous creativity and resilience. It constituted a different form of knowledge than the life experiences of the middle- and upper classes, cushioned by their socio-economic resources, of formal spheres of society, and of the techniques, procedures and rationalities of the state.

The latter aspect, the contrast between the knowledges of the state and popular knowledges, was constantly stressed in Bolivarian discourse. The state's way of doing things was conceptualized as its slow institutionalized procedures, its emphasis on formalities, its faulty capacity to act "in the moment" and improvise, and above all as its lack of knowledge about local realities. These contrasts repeatedly emerged as an issue in interactions 
between the popular sector and state representatives as a way of making explicit that there were two different modes of action, reasoning and making use of knowledge at play.

\section{Capturing Local Realities}

However, the importance of drawing on local knowledge and resources was not only emphasized by the popular sectors. It was also highlighted in the formal procedures of the communal council as well as the ideological discourse surrounding them. In order to form a communal council, the community had to elaborate a written overview of the social genealogy and cultural characteristic of that area. The explicit purpose was that through capturing popular history and making people's common identities and histories explicit, the communal identity-a key factor for making the communal council work-would be strengthened. Moreover, a central task for a newly constituted communal council was to elaborate what was called a diagnostico social (social diagnostic) and a diagnostic communitario (community diagnostic). This implied making a survey of population - their demographic profile, how many people resided in each house and under what conditions, what special needs they might have (medical or otherwise), the community's housing conditions, and so on. It also implied making an overview of the infrastructural characteristic of the community and the availability of services and recreational areas-or lack thereof. They also recorded available human resources in the community, such as laborers and professionals that could participate in developing or executing projects. In order to elaborate the diagnostic, the voceros and voceras of the communal council walked from door to door-preferably on Saturday afternoons or Sundays when people often are at home. Consequently, the diagnostic formed the basis for developing projects according to the community's most pressing needs and joint priorities.

\section{Negotiating Power}

Conflicts and negotiations between the popular sector activists and state officials over how to ground community activism "in the local" played out in a variety of manners. It could be the extent to which local activists were involved in the development and planning of project initiated by the municipality, and who would be employed in the project. It could be over where meetings would take place and when: in a public office during office 
hours (which created a lot of problems for people) or in the barrio at a time when people were off work. It could be over the paper trail necessary for forming communal councils and developing projects, and for delays in getting answers from the institutions, which often caused that the initial community mobilization waned and the project lost its momentum. These conflicts and negotiations were frequently framed by popular activists as fundamental ideological and political problems. In their opinion, the state had not been sufficiently conquered by popular power, and was reluctant to cede space and change procedures accommodating the strengthening of popular power.

For example, in May 2009 I was present at a two-day workshop about the proposal for a new law that would govern the organization of the communes (Ley Orgánica de las Comunas). Consistently with the inventamos o erramos approach, Chávez had suggested that a commune had to be constructed and invented along the way. To that end, several pilot communes had already been set up in different parishes of Caracas before their legal framework had been developed. At the workshop, there was a lot of meta-critique of the revolutionary process. One of the most frequent complaints was that popular power had not gained sufficient space and force. The structures of the state did not allow for people to assume power, and the state did not cede power to people. "The resistance to the poder constituyente (constituent power) has to die," one man said as a metaphor. Another man criticized the Law for the Communal Councils (which was also debated at the time), arguing that it contained several elements that had nothing to do with their everyday life and that the law had to be submitted to popular discussion again (which happened later that year). Another man suggested that people should work with the National Assembly through the Comites de Legislación Popular (Committees for Popular Legislation) and that with time the communes should develop instituciones de gobierno de poder popular (institutions for the government of popular power) that would take over areas of responsibility from contemporary public institutions. ${ }^{4}$

The discursive content of these discussions reflect the deeper ideological debates over what popular power entailed, and the political obstacles toward obtaining it. Debates such as these were quite common in political and public meetings, though primarily taking place among popular intellectuals, political figures and ideologically oriented activists.

However, on a day-to-day basis, numerous less explicit political struggles were also taking place. Many of the participants in the communal 
councils were more concerned with concrete obstacles to their organizational efforts than with ideological debates. The main points of contention were the institutions' lack of flexibility and unwillingness to adapt to their needs. The ways in which the state functionaries, or political figures, dealt with popular complaints varied. Often, public functionaries would be practical and pragmatic; they would listen to community complaints and, as in Miriam's case above, suggest ways of dealing with them. Indeed, more often than not, there were constructive dialogues and respectful interaction between state representatives and community activists, not least when they shared a common socio-economic background and ideological engagement with the Bolivarian process, which was often the case. However, sometimes, public functionaries would try to divert attention away from the complaints that were raised. This would often provoke the anger of the community activists, who were wary of "condescending" and "patronizing" attitudes.

\section{The Meeting that Got Off Track}

Below is an example of such an encounter, at a meeting in 2009 attended by two public officials and several members of communal councils in 23 de Enero. The meeting took place in a community health station in 23 de Enero. I was invited to the meeting by Ricardo, a promotor in Fondemi, to whom I had been introduced at a community meeting the night before. Ricardo was from 23 de Enero at the same time as he served as the promotor for its parish.

Fondemi was another state institution dedicated to channeling funds to projects elaborated by communal councils. Whereas Fundacomunal was financing projects related to housing and infrastructure, Fondemi solely focused on proyectos socio-economicos (socio-economic projects). Only projects developed within the vision of communal, endogenous development could formally be considered for funding. Those involved in the project had to establish themselves as a social or communal co-operative, and parts of the income had to be circulated back into the community in the form of seed money for new economic initiatives or as a social emergency fund (e.g., if someone were in acute need for money for a health emergency or a funeral or if their house collapsed). Furthermore, the projects had to be elaborated in accordance with identified local needs emerging from the diagnóstico communitiario (community diagnostics). For example, if the community did not have a bakery nearby, Fondemi 
could finance the establishment of a co-operative-based bakery. Similarly, the institution could finance the establishment of local manufacturingmany of them supplying school uniforms to the local Bolivarian schools. However, one of the criteria for having a project approved was the use of primary materials. For that reason, Fondemi did not finance business proposals for hairdressers, Internet cafés or DVD rentals. However, Ricardo confided to me that there was flexibility as to which projects were actually approved, in order not to crush the communities' initiatives and energy.

The meeting at 10 am was aimed at informing the spokespeople from the communal banks about how they could work with Fondemi. Chávez had recently announced that the creation of communes was "high priority," and for that purpose, Centros de Formación Socialista (Centers for Socialist Formation) were about to be established in the barrios. These centers were to be educational and informational centers that would function as a meeting place for different community social groups and different state institutions.

Before the meeting started, Ricardo said that he expected 80 people to attend. Only 12 joined. We were sitting outside, on the upper floor of the local health station, which was not open at that hour of the day. A tall slender man in his late thirties, another promotor from Fondemi, was hosting the meeting. A black, intense woman around the same age, who lived in the barrio El Junquito, in the outskirts of eastern Caracas, was also attending. She started the meeting by talking about El Salvador, where Mauricio Funes had won the presidential elections for the left-wing Farabundo Martí National Liberation Front (FMNL) just three days earlier. She was probably trying to incite the revolutionary spirit of those present and put their "domestic revolution" in a larger context. Her attempt failed, triggering a slightly skeptical attitude in the audience. She held a short passionate speech about how El Salvador constituted another front in the left-wing wave that was sweeping the continent, and how they had now woken up from their enslavement. She then proposed that the participants offer their views on the issue, but people were just staring, slightly confused and amused by her. A few people eventually spoke about the recent events in El Salvador, but her speech did evidently not generate the enthusiasm she was hoping for.

It soon became clear that it was the practical day-to-day challenges that the voceros wanted to discuss. One member said that he had tried to develop a project that involved Fondemi, but Fondemi demanded that all five voceros in the communal councils attend a five-day seminar, when 
it was obvious, he said, that people could not do that, as they needed to work. He finished by alluding to Chávez's call for everyone to come out in the streets and work after the victory on February 15. "But people have been in the streets all the time since the process started. It is the institutions that have remained inside the walls!"

Another man said that his communal council was also told to attend seminars by Fondemi but that they could not go either because of work. "They are not responding to the needs of el pueblo, but to the needs of Fondemi," he stated firmly. The next speaker said that he could only speak from personal experience and that he had just started working in the communal councils, but so far he felt that they had received satisfactory responses from the institutions. The next speaker said that they all had to exercise control over the institutions and that the institutions needed to have a flexible time schedule that suited people, not the bureaucracy. If not, people would become demotivated. In their case, they had started to work on a project for one of the bloques in their community, up in the El Mirador sector. The bloques were falling apart, and they had taken photos and had received visits from people from the institution. As there had not been subsequent follow-up from the state, the initial interest waned and people lost their enthusiasm.

The woman from Fondemi then said that, certainly, within the institutions there were people who didn't work as they should and who bacen trampas (play tricks); "but we, as revolutionaries are above this," she said. Revolutionaries do not have their own lives, she continued. She used her own sacrifice for the revolution as an example, how she was working day and night, coming home late to her children. She acknowledged, however, that many people were working and could not go to all the meetings all the time. What the communities needed to understand was that the communal councils represented la nueva institucionalidad (new institutionalism), and that the communal councils were not only composed by the voceros, but by the whole community. "So if the voceros cannot come, another member from the community should go instead," she stated. She used their meeting as an example and said that those convoked were the heads of the communal bank, and they were there not only for themselves, but also for the whole community. They needed to go back and inform everyone about what had taken place at the meeting. "We are all a part of the process and we all need to contribute to developing all of us," she said.

She continued talking about how the process of the communal councils was a "trying, failing and learning process," and that it was easy to blame the institutions when something went wrong. But the communities also 
had to look at what they did. "Take the problem with money that 'disappears.' Millions have been bajados (channeled down) to the communities for infrastructure projects. Millions of gotas de petroleo (drops of oil), but no one in the communities has so far been jailed for corruption."

After a bit of back and forth over this topic, she announced that it was time to get instructed on how to develop the community projects. The semana de formación (education week) started in April, and they would accommodate people's schedules so everyone could attend. One man asked if they would be getting money for transport to and from the meeting, and was told that they would not. "Chávez says that as a revolutionary one has to work 23 hours a day, and as a revolutionary one has to move around." Again, the woman from Fondemi referred to herself and to how she the other day got home at $11 \mathrm{pm}$, to El Junquito where she lived. "I was worried about the kids, it was late and it was dangerous." One man responded in a slightly sarcastic tone: "No one doubts your compromise, negrita." 6

In my fieldnotes from the meeting, I noted that people at the meeting were becoming warier toward the woman from Fondemi as they were trying to raise real issues, while she was trying to focus on "ideological tutoring." At the time I was puzzled by the fact that the promotor leading the meeting was unusually "out of sync" with the people present, especially since she was a lower-level public functionary from a barrio. I was later told by another worker in Fundacomunal that promotores had recently been instructed by their superiors to hold an inspirational and educational speech before meetings in order to foment consciousness about the larger context of their day-to-day struggle, which explained why the promotor seemed out of touch from the very beginning in this particular meeting.

Several researchers have noted the high level of politicization of the communal councils (e.g., Álvarez and García-Guadilla 2011), but as this episode illustrates, the "recipients" of ideological touting are hardly passive subjects. If people didn't like the content of the meeting, whether because of ideological touting or for other reasons, they would deploy a range of "strategies of resistance" such as being sarcastic, leaving, talking among themselves, talking back, quarrelling or playing with their mobile phones, amounting to local variants of Weapons of the Weak (Scott 1985). Moreover, the push toward picking up on ideological subject often came from popular sector activists themselves, who used it as a discursive tool to criticize the state institutions' deficiencies and unwillingness to assume a revolutionary agenda. 


\section{Negotiating Hierarchy}

We have previously referred to the popular sector's contestation of the cultural hegemony and politics of the state. A key aspect of this struggle was to challenge class distinctions inscribed in the hierarchy among grassroots activists, barrio residents and state officials. As previously noted, the social composition of the Venezuelan state and political class has undergone a shift, and there are now more people from popular- and leftist radical backgrounds occupying these positions. At one level, this changed the form of interaction between people and the state because of increased socio-economic and political proximity, at the same time as the inherent hierarchical relationship between the inside/outside of state power shaped new strategies of subjugation and resistance. Much emphasis was placed on under-communicating power differences and hierarchies between el pueblo and officials, at the same time as these hierarchies were constantly negotiated-sometimes directly and sometimes indirectly. In particular, representatives of the state and the government frequently alluded to poder popular in order to signalize that they were aligned with el pueblo, at the same time as people used the concept of popular power as a discursive strategy to push or challenge state and political officials.

Moreover, political discourse was markedly "popularized," in the sense that it was explicitly anti-elitist. A prime example of this popularization was of course Chávez, who mastered the popular language to the fingertips, even when he spoke about complex political and economic issues. However, a popularized political discourse, emphasizing informality and colloquiality, was deployed in a variety of settings. This included the interaction between high-level politicians and public functionaries and community members. In the following example, we will see how this played out at a public meeting in 23 de Enero with Jorge Rodriguez, the thenmayor of the Libertador Municipality.

\section{A Visit from the Mayor}

The purpose of the meeting was the inauguration of the new mayor's pilot program: Plan Caracas Socialista. Plan Caracas Socialista was an urban infrastructure program that would be carried out in close cooperation with the communities through the formation of gabinetes sectoriales (sectorial cabinets), which would include all social movements (communal 
councils, colectivos and other groups) in the area and the representatives from the municipality.

The meeting took place at Plaza la Juventud in La Cañada, located between the bloques and the road leading up the roundabout of bloque seven. A small stage was set up, with rows of chairs under a red-and-white baldaquin. A lot of people showed up, both from La Cañada and adjacent sectors. After having been introduced by Guadalupe, one of the leaders for the Colectivo Coordinadora Simón Bolívar, Jorge Rodriguez greeted the community and started to explain how the projects would proceed. At one point, in the midst of the explanation, a man in the audience shouted from the back: "But what about barrio Sucre?" Rodriguez responded: "Ah, I'm getting there, compadre, I am getting there." Later in his speech, another woman shouted out: "In El Observatorio there are bloques without doors," to which Rodriguez responded "I know amor mio, like I am telling you, in less than a month we will start up there." Throughout his speech, he often used hermanas and hermanos (brothers and sisters) to address the crowd.

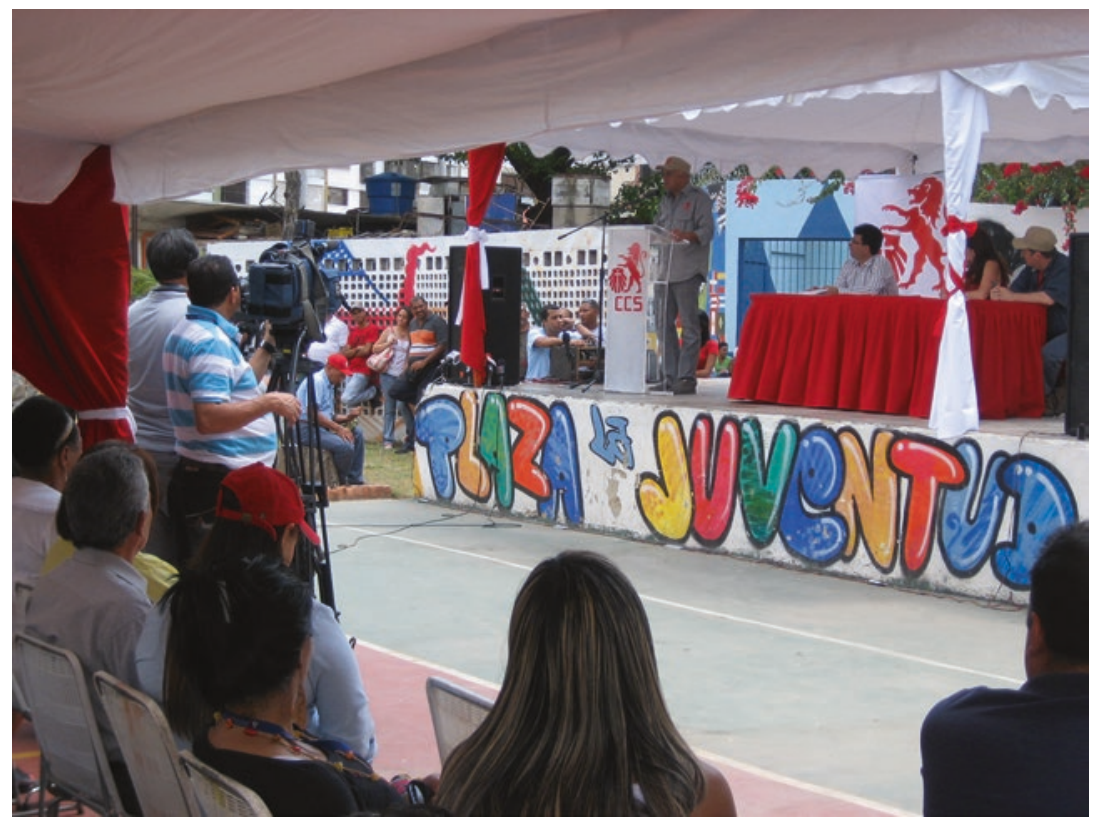

Photo 7.3 Public meeting with Jorge Rodríguez, the mayor of the Libertador Municipality, in 23 de Enero. Photo by the author 
Rodriguez's choice of words is not insignificant. Compadre, literally meaning godfather, is an expression that is most commonly used between equals. Similarly, amor mio, my love, is a colloquial way of addressing both friends and strangers (e.g., in shops) though the form mi amor is more common. Hermano and hermana are also ways to address other people to indicate equality and friendliness. By using these forms to respond to comments, Rodriguez was signaling colloquiality, equality and intimacy. ${ }^{7}$

Jorge Rodriguez, a psychiatrist by trade, is the son of Jorge Rodriguez, the leader of the political movement and party, Liga Socialista, who was beaten to death by security agents in 1976. Even though Rodriguez has a middle-class background, he has intimate knowledge of popular sector political discourse and sociality.

The social and political background of the Chavista leadership is significant for understanding how the social interaction between popular sector communities and public officials unfolded within the Bolivarian space. As Caldeira notes: "In hierarchical societies, access to political speech is generally a privilege of the dominant class. Word and power are associated" (Caldeira 1988:452). Through the Bolivarian process, the poor acquired an advanced mastery of political speech, and they frequently had access to forums where they could engage with politicians directly. Moreover, politicians and community activists shared the political discourse and symbolic universe of the Latin American left. This created a platform for negotiating differences through discourse as the popular sectors could assert themselves through rhetorical devices and political references autochthonous to them.

\section{WanT TO TALK ToO}

The following example illustrates how the notion of popular power was invoked to negotiate hierarchy at a meeting concerning the passing of the new law for the communal councils in 2009. A large tent, in white and red, had been set up outside the National Assembly, downtown Caracas. Various representatives from the National Assembly and community activists were present. The members of the Comision Permanente de Participación Ciudadana, Descentralización y Desarrollo Regional (Permanent Committee for Citizen Participation, Decentralization and Regional Development) held long speeches about the loopholes in the 2006 law, and about the new provisions of the reformed law. Afterward, 
the floor was opened to questions. Nicolas, an elderly man from a communal council in El Junquito took the microphone and said:

First of all I want to greet my beloved comandante Hugo Rafael Chávez Frías for moving this forward, for being fascinated, ${ }^{8}$ and secondly, to the representatives that have spoken because they have dedicated themselves really, paying attention to details and I am really satisfied with how this is going. Now, listen, I want to propose that there isn't only space for questions here, because si yo soy poder popular (if I am popular power) it cannot be that you only allow me to ask a question, I want to say something in depth.

Nicolas then made a lengthy and well-formulated speech that was well received by the audience. Afterward, one of the national assembly representatives followed up on some of the points Nicolas had made in a respectful and serious manner. As Sharma and Gupta note: "Everyday statist encounters not only shape people's imagination of what the state is and how it is demarcated, but also enable people to devise strategies of resistance to this imagined state" (Sharma and Gupta 2006:17). Through his speech, Nicholas signalized that the state representatives could not set themselves above the representatives of popular power through dictating the agenda and form of the meeting. His choice of words was readily understood by the members of the National Assembly, who then adapted to the claims that he was making. Indeed, more often than not, power holders would put emphasis on signalizing equality and that the floor was open for debate. However, on a few occasions, I observed more conflictual dynamics emerging from the trespassing of acceptable displays of power and hierarchical difference.

\section{Deflecting Criticism}

One such occasion was a meeting in the national theater of El Capitolio, in the center of Caracas. It was an important event, and the mayor, the minister of culture, the minister of the commune and Jacqueline Farías, the head of the government of the Capital District (Distrito Capital), were supposed to be present, together with representatives from the communal councils from all across western Caracas. The purpose of the meeting was to present a summary of the proposals that had been elaborated by extensive popular participation for the reform of the Law for Communal Councils. 
Parallel popular assemblies had taken place all across Caracas in the previous weeks, and involved approximately 2600 people. The assemblies were organized both as plenary discussions and as work groups, where each group, comprising of an average of 35 people, had elaborated a detailed analysis, with corresponding proposals for reforms of the law, for the communal councils. From all this work, five documents, each representing one eje (axis) of Caracas, ${ }^{9}$ had been elaborated, summarizing different points of view, which were now to be officially presented to the authorities. This would form the basis for the reform.

The meeting was scheduled to take place on Sunday at $10 \mathrm{am}$, but it didn't start until about three hours later. In the meantime, those who waited outside and inside the theater had been given breakfast in takeaway boxes-yogurt, ham and cheese sandwiches and orange juice. When the meeting finally started, it was announced that neither the mayor nor the minister for the commune would come. The leader of the meeting was Jacqueline Farías who held an introductory speech, after which the spokespeople for the five axes presented their main points on Power Point slides.

Many people were eager to address the panel, but Farías said that a general discussion was not scheduled and would not take place. One woman took the microphone and shouted angrily: "We have been here since nine o'clock in the morning, and now you are telling us that only five people are allowed to speak? Everyone who wants to should be allowed to speak." A heated discussion erupted as others joined the woman's protest.

To distract the crowd, Jacqueline Farías stated that "we have more important enemies than our own politicians" and that "here we are all from el pueblo, and even if today I have this position, on another occasion it will be you." In my field notes, I wrote that she seemed a bit defensive and that her attempts to distract came across as quite patronizing. She was saved by a young woman from Gramoven, an area in Catia that was known for high levels of organization, who was a relatively well-known community activist. She argued that the political representatives were doing the best they could to attend to all the different areas they were responsible for. Shortly thereafter, the discussion died out, and the meeting ended. It was obvious that some of the people wanted a discussion with more substance, as they had put in a lot of time and effort into working out these proposals. (The previous day I had participated in a full-day discussion and summary session in the axis that corresponded to 23 de Enero.) The fact that the few politicians that actually showed had showed up late (even though no meeting ever starts on time) added to the frustration. 


\section{A Contested Bolivarian Space}

Throughout the past three chapters, we have explored, from various angles, the interface between popular politics and state politics within what I have called a Bolivarian space. I have emphasized the contested, conflictive and at times contradictory dynamics that emerged as the ideals, ideology and politics of the Bolivarian process rubbed against political structures, ingrained social practices and heterogeneous social actors and interests. In particular, I have emphasized an in-depth understanding of "the local" as a point of departure for understanding how grassroots politics was unfolding with popular sector communities and in close interaction with the state.

Chapter 8 will continue this line of exploration, but from a different angle. We will now turn our attention to how the templates, practices and values associated with oil wealth gained salience in the crafting of a Bolivarian ideology and corresponding new social, cultural and political practices. Specifically, I will explore how notions of money, wealth, consumption, individualism, greed, and corruption can be traced back to the nation's history as an extractive state. Concurrently, I will show how these contested moralities and values translated into a deeply ambivalent and unstable terrain for the unfolding of the Bolivarian process at the level of everyday political dynamics as well as for its ideological underpinnings.

\section{Notes}

1. This event took place in the spring of 2009. In order to adapt to the new legal framework of the reformed law from the communal councils, the councils had to go through a process called adequacion (adjustment), which implied calling for new elections and re-registering with Fundacomunal.

2. Fieldwork interview, Eliér Gonzales, director of Fundacomunal in western Caracas, spring 2009.

3. Fondemi is a state institution that gives credits (which have to be repaid) to socio-economic projects boosting local economic activity.

4. The communes were envisioned as progressively becoming instances of auto-gobierno (self-government) consistent with the ethos of the Socialism for the twenty-first century.

5. This was a referendum over amendments of five articles of the constitution (a modification of the original proposal that was turned down in a referendum in 2007, see Chap. 4).

6. Note that negrita is not meant disrespectfully in this context. It is a common expression among peers, both used for those who clearly have African heritage and for those that have a whiter skin tone. 
7. In Bolivarian political discourse, compañeros/as is the most common way of referring to someone. It is also frequently used in political settings where politicians or public officials interact. It is important to note that Venezuelans are relatively more informal in their everyday interactions than in many other Latin American countries. The formal version of the pronoun you, usted, is frequently omitted in everyday speech, and people commonly address each other as tú (informal version of you). Professional titles are however frequently emphasized in formal and semi-formal settings (e.g., licenciado/a, doctor/a, maestro/a, professor/a) and pupils and students commonly address their teachers as maestro/a or professor/a. Usted may be used out of respect in some contexts signalizing formality or hierarchies, and it can also be used to maintain a certain distance from a speaker. In the street, people address each other in a number of ways according to sex and gender. Mi amor (my love) is a relatively common way to address strangers in a range of everyday context, both men and women. Men can address each other as pana (buddy) or hermano (brother) if they want to create a situation of friendliness or informality, even to a stranger.

8. Fascinated, in this context, means engaged, dedicated.

9. The division of Caracas into axes (ejes) is a part of the new geo-political restructuring that was proposed by Chávez in his amendments to the constitution. The different axes are based on strategic evaluation of the characteristics, needs and potential of each area, constituting an "overlapping" political map, in addition to the formal territorial divisions between parishes and municipalities.

\section{BiBLIOGRAPHY}

Alvarez, Rosángel, and María Pilar García-Guadilla. 2011. Controlaría social y clientelismo: La praxis de los consejos comunales en Venezuela. Politeia 34 (46): 175-207.

Appadurai, Arjun. 1990. Disjuncture and Difference in the Global Cultural Economy. Public Culture 2 (2): 1-24.

Caldeira, Teresa. 1988. The Art of Being Indirect: Talking about Politics in Brazil. Cultural Anthropology 3 (4): 444-454.

Ciccariello-Maher, George. 2016. Building the Commune. Radical Democracy in Venezuela. London and New York: Verso.

Cooke, Bill, and Una Kothari. 2001. Participation: The New Tyranny? London and New York: Zed Books.

Ellner, Steve. 2009. A New Model with Rough Edges: Venezuela's Community Councils. NACLA Report on the Americas 42 (3) (May/June): 11-14.

Ferguson, James. 1994. The Anti-Politics Machine: Development, Depolitization and Bureaucratic Power in Lesotho. Minneapolis and London: University of Minnesota Press. 
Fernandes, Sujatha. 2007. Barrio Women and Popular Politics in Chávez's Venezuela. Latin American Politics and Society 49 (3): 97-127.

Gupta, Akhil. 1995. Blurred Boundaries: The Discourse of Corruption, the Culture of Politics, and the Imagined State. In The Anthropology of the State. A Reader, ed. A. Sharma and A. Gupta. Oxford: Blackwell Publishing.

- 2001. Governing Populations: The Integrated Child Development Services Program in India. In States of Imagination. Ethnographic Explorations of the Postcolonial State, ed. T.B. Hansen and F. Stepputat. Durham and London: Duke University Press.

Irazábal, Clara, and John Foley. 2010. Reflections on the Venezuelan Transition from a Capitalist Representative to a Socialist Participatory Democracy. What Are Planners to Do? Latin American Perspectives 37 (1): 97-122.

López, Margarita M. 2011. Hacia el socialismo del siglo XXI: Los consejos comunales, sus cambios conceptuales y las percepciones de los participantes en Caracas. In Ciudadania y Legitimidad Democrática en América Latina, ed. I. Cheresky. Buenos Aires: Prometeo.

Machado M., Jesús E. 2009. Participación social y consejos comunales en Venezuela. Revista Venezolana de Economía y Ciencias Sociales 15 (1): 173-185.

McNeish, John-Andrew. 2001. Pueblo Chico, Infierno Grande. Globalisation and the Politics of Participation in Highland Bolivia. PhD dissertation, Department of Anthropology, University of London.

Mitchell, Timothy. 2006. Society, Economy and the State Effect. In The Anthropology of the State. A Reader, ed. A. Sharma and A. Gupta. Oxford: Blackwell Publishing.

Motta, Sara. 2013. "We Are the Ones We Have Been Waiting For": The Feminization of Resistance in Venezuela. Latin American Perspectives 40 (4): 35-54.

Pedrazzini, Yves, and Sanchez R. Magaly. 1992. Malandros, Bandas y Niños de la Calle. Cultura de Urgencia en la Metropoli Latinoamericana. Valencia and Caracas: Vadell Hermanos Editorial.

Pigg, Stacy Lee. 1996. The Credible and the Credulous: The Question of "Villagers' Believes" in Nepal. Cultural Anthropology 11 (2): 160-201.

Rakowski, Cathy A., and Gioconda Espina. 2011. Advancing Women's Rights from Inside and Outside the Bolivarian Revolution, 1998-2010. In The Revolution in Venezuela. Social and Political Change under Chávez, ed. T. Ponniah and J. Eastwood. Cambridge, MA: David Rockefeller Center for Latin American Studies, Harvard University.

Scott, James. 1985. Weapons of the Weak. Everyday Forms of Peasant Resistance. New Haven and London: Yale University Press.

-1999. Seeing Like a State: How Certain Schemes to Improve the Human Condition Have Failed. New Haven and London: Yale University Press.

Sharma, Aradhana, and Akhil Gupta. 2006. The Anthropology of the State: A Reader. Oxford: Blackwell Publishing. 
Strønen, Iselin Åsedotter. 2013. En feministisk revolusjon? Kvinner, kvinnekamp og aktivisme i Chávez' Venezuela. Norsk Antropologisk Tidsskrift 1 (24): 39-51.

Sunstein, Cass. 1998. More Is Less. Review Article of Seeing Like a State: How Certain Schemes to Improve the Human Condition Have Failed by James Scott. The New Republic 37.

Willson, Margaret. 2007. Dance Lest We All Fall Down: Breaking Cycles of Poverty in Brazil and Beyond. Seattle: University of Washington Press.

Open Access This chapter is distributed under the terms of the Creative Commons Attribution 4.0 International License (http://creativecommons.org/ licenses/by $/ 4.0 /$ ), which permits use, duplication, adaptation, distribution and reproduction in any medium or format, as long as you give appropriate credit to the original author(s) and the source, provide a link to the Creative Commons license and indicate if changes were made

The images or other third party material in this chapter are included in the chapter's Creative Commons license, unless indicated otherwise in a credit line to the material. If material is not included in the chapter's Creative Commons license and your intended use is not permitted by statutory regulation or exceeds the permitted use, you will need to obtain permission directly from the copyright holder.

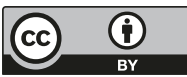

